\title{
PENTINGNYA PENDIDIKAN BAGI ANAK KORBAN PEMERKOSAAN
}

\author{
${ }^{1}$ Riza Gineung Adi Anggara, ${ }^{2}$ Kevin Sianturi, \\ 3Debora Wibi Florency, dan ${ }^{4}$ Tomy Michael \\ 1,2,3,4Fakultas Hukum Universitas 17 Agustus 1945 Surabaya \\ 1gineungriza@gmail.com \\ 2kvnsntr@gmail.com \\ 3florencyd6@gmail.com \\ ${ }^{4}$ tomy@untag-sby.ac.id
}

\begin{abstract}
The aim of the research is to broaden a legal perspective that child victims of sexual violence are victims and must be protected, not to be disputed. By using empirical methods that are conceptualized as a symptom, the extent to which they carry out their duties, principles and functions in their implementation or reality in educational institutions. In this study, researchers offer an update in this education system, namely the addition of sex education subjects in primary to secondary schools or majors so that children at an early age can be understand the function and the meaning of a vital organs, so that acts of harassment from an early age can be prevented. In this present time various forms of crime are very widespread, ranging from sexual crimes and so on. Sexual crime is not only experienced by adult women, but children are also be victims. The children of the victims are worried because it could ruin their future. The factors also vary, from physical factors to technological factors because it is easy to access pornographic content.
\end{abstract}

Keywords: Child, Sexual Violence, Victim, Rape, Sexual Education

\section{Abstrak}

Tujuan penelitian ialah memperluas suatu wawasan hukum bahwasannya anak korban dari kekerasan seksual adalah korban dan harus dillindungi, bukan untuk didiskrimansi. Dengan menggunakan metode empiris yang dikonsepkan sebagai suatu gejala, sejauh mana menjalankan tugas, pokok, dan fungsinya dalam pelaksanaannya atau kenyataan pada lembaga pendidikan. Pada penelitian ini, peneliti menawarkan pembaruan dalam sistem pendidikan ini, yaitu dengan ditambahnya mata pelajaran sex education pada sekolah dasar hingga menengah atau kejurusan sehingga anak seusia dini dapat memahami atau mengerti fungsi dan makna dari suatu organ-organ vital, sehingga tindakan pelecehan sejak dini dapat dicegah. Dalam masa sekarang ini berbagai bentuk kejahatan sangat merebak, mulai dari kejahatan seksual dan sebagainya. Kejahatan seksual ini tidak hanyanya dialami wanita dewasa saja, tetapi anak-anak pun juga menjadi korban. Korban yang masih anak-anak ini yang dikawatirkan karena dapat merusak masa depannya. Faktornya pun bermacam-macam, mulai dari faktor fisik seperti penampilan wanita yang terbuka hingga karena faktor teknologi yang mudah sekali untuk mengakses konten porno.

Kata Kunci: Anak, Kekerasan Seksual, Korban, Pemerkosaan, Pendidikan Seksual 


\section{PENDAHULUAN}

Dalam potret Hak Asasi Manusia terdapat suatu mosaik-mosaik tentang kemerdekaan, kebebasan, keadilan, persamaan, perdamaian, persaudaraan dan perlindungan. Begitu pula dengan Hak anak yang merupakan anak dari suatu Hak Asasi Manusia (HAM) yang terdapat suatu gambaran bahwa anak telah terpenuhi haknya untuk dijamin dan juga dilindungi hak-hak seorang anak supaya bisa hidup layak, tumbuh juga berkembang, bahkan berpartisipasi, dengan tepat sesuai dengan harkat dan juga martabat kemanusiaan, pun mendapat perlindunganyang sesuai dari diskriminasi juga tindakan kekerasan. Gambaran itupun pasang surut telah mengalami kesuraman, bahwasannya penindasan "pelanggaran" terhadap Hak Asasi Manusia merupakan fenomena musnahnya arti kebebasan atau kemerdekaan itu hampir menjadi kenyataan. Manusia telah diikat oleh masalah yang dibuatnya sendiri. masalah inilah yang membuat sebagian orang merasa kehilangan arah dan tujuan. Diam mempunyai ambisi, keinginan, dan juga tuntutan yang diikuti oleh nafsu, tapi karena hasrat yang berlebihan gagal ia kendalikan yang berakibat masalah yang dihadapinya makin terasa berat (Wahid, 2007).

Kejahatan Seksual, Bahkan tidak hanya terjadi pada perempuan dewasa tetapi sering terjadi juga pada perempuan di bawah umur yang biasa disebut anak-anak. kejahatan seksualpun tidak Cuma berlangsung di dalam lingkungan perusahaan atau perkantoran dan juga ditempat tertentu, tetapi dapat terjadi pula dalam lingkungan keluarga bahkan lingkungan sekolah. ini yang sangat memprihatinkan dimana makin maraknya kejahatan seksual yang menimpa anak di bawah umur. Anak-anak perempuan dijadikan sebagai objek komoditas untuk memuaskan nafsu bejat dari penjahat seksual, bahkan didalam dunia pendidikan pun, anak dari korban pemerkosaan tersebut terlalaiakan atau terkadang pihak sekolah pun tidak mau aib sekolah tersebut tercoreng dikarenakan terdapat siswinya yang tengah berbadan dua akibat pemerkosaan, sehingga hilangnya jaminan masa depan bagi korban tersebut (Wahid, 2007). Oleh karena itu dalam menangani persoalan terkait sex education haruslah sangat teliti mengingat generasi yang kita alami saat ini sangatlah miris. Masih banyak hal hal yang perlu di perhatikan dengan adanya perkembangan jaman yang semakin modern ini dengan sangatlah mudah mengakses situs situs yang menjurus ke pelecehan seksual terhadap lawan jenis yang pada saat kita temui serta bisa dikatakan bahwa itu bukan mahramnya jika orang tersebut beragama muslim. Maka dari itu pentinglah kami membuat suatu penelitian ini agar dimana masyarakat yang notabenenya belum mengenal maupun mengerti terkait tentang permasalahan sex education dan ini juga bisa menambah wawasan bagi sang penulis tersendiri, kemauan itulah yang menjadi potensi tersendiri oleh sang pelaku jika ingin membuat suatu hal yang semestinya tidak boleh dilakukan. Ada perubahan yang terjadi dimana dapat menghadirkan suasana yang harmonis dan juga disharmonis, tergantung bagaimana muatan pengaruh yang akan ditawarkan dan juga dipaksakan mempenggaruhi pola pikir hidup dan juga model interaksi sosial, kultural, ekonomi, hukum dan juga politik yang dibangunnya. Kemauan yang menjadi potensi di dalam 
diri manusia sangat berperan menjadi penentu terjadi peningkatan perilaku yang mendatangkan kebaikan bagi kehidupan antara sesama manusia dan sebaliknya (Yanhtzi, 2009). Para ahli telah mengemukakan bahwa, pada pribadi manusia pasti ada kemauan agar hidupnya menjadi sebuah sumber terhadap potensi kreatifitas, tapi adanya kemauan itu dalam pribadi manusia itu, pasti akan ada keinginan berkuasa,dimana menjadi sumber dari setiap tindakan destruksif. Bisa sebut destruktif karena untuk power ini tidak akan mengenal yang namanya akhir, tidak akan mengenal batas, dan mungkin tidak mengenal namanya yang cukup yang berakibat terjadinya konflik, dimana terjadi tolak belakang antara kemauan untuk hidup dan keinginan-keinginan lainnya. Manusia bahkan kadang gagal untuk mencegah dirinya melakukan hal yang jahat, dikarenakan oleh kepentingan ekonomi/materi, oleh tuntutan biologis, oleh berbagai kompetisi, dan juga status dan harga dirinya. Padahal perbuatannya merupakan bentuk pelanggaran terhadap norma-norma dan juga nilai-nilai kemanusiaan (Yanhtzi, 2009). Berdasarkan latar belakang di atas maka tujuan penelitian ini adalah untuk mengetahui faktor apa saja yang menyebabkan terjadinya pemerkosaan terhadap anak, serta jaminan pendidikan bagi korban pemerkosaan.

\section{METODE PENELITIAN}

Metode penelitian merupakan cara atau upaya untuk mencari hal sesuatu untuk mencapai suatu tujuan dengan dengan cara mencari, mencatat, merumuskan dan menganalisis laporan. Penelitian ini merupakan kegiatan ilmiah yang disusun secara sistematis dan memilki tujuan. Oleh karena itu, informasi yang dikumpulkan harus relevan dengan persoalan yang dikaji. Dalam penulisan ini penulis menggunakan metode penelitian hukum empiris. Penelitian hukum empiris merupakan hukum yang dikonsepkan sebagai gejala empiris yang sejauh mana menjalankan tugas, pokok, dan fungsinya dalam pelaksanaannya atau kenyataan dalam masyarakat (Butarbutar, 2018).

\section{HASIL PENELITIAN DAN PEMBAHASAN}

\section{Faktor Terjadinya Kekerasan Seksual / Pemerkosaan Pada Anak}

Berdasarkan hasil wawancara kami, factor terjadinya pemerkosaan terhadap anak adalah:

1. Faktor fisik pada anak

Dimana fisik anak masih terbilang lemah khususnya pada anak perempuan, oleh karena itu anak menjadi takut untuk melakukan perlawanan. Hal itu yang membuat penjahat seks melakukan kejahatan seks terhadap anak.

2. Faktor kemajuan teknologi

Dengan kemajuan teknologi yang luar biasa pesatnya, kita dapat mengakses semua informasi yang ada dibelahan bumi manapun, begitu pula dengan peredaran materi pornografi, beredar dengan gampangnya dan bisa diakses 
dengan gampang menggunakan alat komunikasi yang kita punya. Itulah yang menjadi salah satu pemicu terjadinya pemerkosaan terhadap anak, dimana sesudah melihat material atau konten pornografi membuat otak orang menjadi rusak dan gairah seksualnya menjadi meningkat dengan adanya kesempatan dan karena anak-anak gampang dibujuk dengan mainan dan lainnya sehingga anaklah yang menjadi sasaran empuk utuk memuaskan gairah seksual pelaku (Ilmu, 2019).

3. Kurangnya edukasi tentang seks

Di Indonesia sendiri masyarakat masih memandang pembahasan atau edukasi tentang seks sangat tabu. Padahal edukasi tentang seks sangat penting buat anakanak, dimana pengetahuan anak untuk mengenali fungsi tubuhnya, memahami etika dan norma sosial serta konsekuensi dari setiap perbuatannya. Tanpa edukasi seks, rasa penasaran pada anak akan berakibat ia mengambil keputusan yang tidak bijaksana saat mengeksplorasi seksualitasnya. Dengan begitu anak tidak mengerti tentang pentingnya melindungi tubuhnya dari penjahat seks. Dan ini menjadi peluang bagi penjahat seks untuk melakukan kejahatan seks.

\section{Dampak Dari Kekerasan Seksual / Pemerkosaan}

Peningkatan laporan kasus perkosaan pada anak dari tahun ke tahun yang terjadi terus menerus, yang dilansir dari laporan KPAI selama tahun 2019, tercatat 2.607 kasus tentang kekerasan yang dialami anak-anak. Yang meningkat dari tahun 2015 dimana tercatat 2.413 kasus. 1.020 dimana setara dengan 62,7\% dari jumlah angka itu merupakan kasus tentang kekerasan seksual berupa pencabulan serta incest, perkosaan, sodomi, dan lebihnya yaitu kekerasan terjadi secara fisik dan juga psikis.

Korban dari perkosaan sangat berpeluang mengalami trauma yang parah dikarenakan peristiwa keji tersebut. Itu membuat korban tergoncangkan kejiwaan yang dialami setelah peristiwa keji tersebut juga bisa disertai dengan reaksi, seperti reaksi fisik juga psikis, peristiwa itupun bisa berdampak jangka pendek bahkan lebih parahnya berdampak jangka panjang. Dampak tersebut ialah proses dimana adaptasinya sesudah seseorang mengalami peristiwa yang traumatis. Korban tersebut bisa menjadi sedih, menyalahkan dirinya sendiri, iapun merasa sangat takut dimana mengakibatkan korban tidak mau bersosialisasi dan menyendiri. Korban cendrung sulit dalam menghapus peristiwa buruk atau/traumanya di dalam alam bawah sadarnya. Ada juga sebagian merasa malu untuk berkomunikasi dengan orang lainnya, merasa takut akibat pemerkosaan yang menimbulkan kehamilan. Bahkan, tidak sedikit pula korban yang mengalami depresi berat akibat pemerkosaan itu ingin mencoba untuk menghilangkan nyawanya atau sering dikatakan bunuh diri (Ekandari, 2001).

Dampak lainnya yaitu, korban mengalami kehamilan yang tidak diinginkan korban maupun keluarga korban akibat perkosaan. Korban dari perkosaan yang berdampak kehamilan kebanyakan tidak dibolehkan melanjutkan pendidikannya. 
Hal inipun juga dikarenakan beberapa dari pihak sekolah memutuskan agar mengeluarkan siswi hamil itu beralasan dimana kehamilannya menjadi aib dimana dapat merusak nama sekolah (Ekandari, 2001).

\section{Jaminan Bagi Pendidikan Bagi Korban Pemerkosaan Yang Masih Sekolah}

Berdasarkan penelitian kami dengan melakukan wawancara terhadap lembaga pendidikan yaitu, lembaga pendidikan bertanggung jawab akan pendidikan bagi anak korban pemerkosaan agar bisa mendapatkan pendidikan dengan baik selayaknya anak-anak lainnya karena anak korban pemerkosaan mempunyai hak untuk mendapatkan pendidikan dan tidak adanya perbedaan dalam mendapatkan pendidikan sesuai denganUU No. 39 tahun 1999 tentang Hak Asasi Manusia

\section{- Pasal 12}

"Setiap orang berhak atas perlindungan bagi pengembangan pribadinya, untuk memperoleh pendidikan, mencerdaskan dirinya, dan meningkatkan kualitas hidupnya agar menjadi manusia yang beriman, bertaqwa, bertanggungjawab.

- Pasal 60

"Setiap anak berhak untuk memperoleh pendidikan dan pengajaran dalam rangka pengembangan pribadinya sesuai dengan minat, bakat, dan tingkat kecerdasannya".

Jadi pada dasarnya pemerintah dan lembaga pendidikan bertugas melindungi warga negaranya agar memperoleh hak-haknya untuk mendapatkan pendidikan yang layak dan setinggi-tingginya, baik dewasa maupun anak-anak (Emmanuel, 2010). Meskipun dalam keaadan hamil karna pemerkosaan yang terjadi, tetap saja mempunyai hak untuk mendapatkan pendidikan dan juga lembaga pendidikan harus melindungi identitas anak dari media massa agar menghindari labelisati pada anak korban pemerkosaan. Dan juga lembaga pendidikan tidak akan mengeluarkan peserta didik yang menjadi korban pemerkosaan dari sekolah dengan alasan apapun. Jadi jika ada siswi korban dari pemerkosaan yang sedang hamil, maka pihak sekolahan akan memberikan dispensasi kepada murid tersebut, sehingga siswi tersebut dapat waktu untuk rehabilitasi. Pasal 64 ayat (3) UU No. 35 Tahun 2014 menyatakan, anak sebagai korban mendapatkan rehabilitasi baik dalam lembaga maupun luar lembaga, perlindungan identitas di media massa untuk menghindari labelisasi, pemberian jaminan keselamatan bagi saksi korban dan saksi ahli baik fisik, mental, maupun sosial. Undang-Undang No. 35 tahun 2014 secara legal formal menjadi regulasi yang mengatur mengenai perlindungan hak anak, undang-undang ini menjadi perpanjangan dari ratifikasi Indonesia terhadap Konvensi Hak Anak (Convention on the Rights of the Child). Lebih dari itu, pemerintah Indonesia juga telah meratifikasi CEDAW (Convention on the Elimination of All Forms of Discrimination Against Women) yang menjadi salah satu basis bagi upaya penghapusan terhadap segala bentuk kekerasan dan diskriminasi terhadap perempuan. Segala peraturan yang melindungi hak-hak anak tersebut dimaksudkan agar siswi tidak mendapat perlakuan 
diskriminatif dari lingkungan keluarga, masyarakat, terutama sekolah. Pendidikan tentang Hak Anak diakui sebagai langkah pertama dari pendidikan Hak Asasi Manusia. Anak-anak adalah kelompok pertama, pemegang hak pertama dan juga yang pertama belajar tentang pendidikan Hak Asasi Manusia. Anak-anak harus dididik dalam hak-hak mereka karena Anak-anak adalah subyek dari hak-hak mereka sendiri, dengan hak dan tanggung jawab sesuai dengan usianya dan tahap perkembangannya anak telah menjadi pemegang hak yang terikat secara hukum (Agnitasari, 2017).

\section{Sanksi Bagi Sekolah Yang Mengeluarkan Korban Kekerasan Seksual / Pemerkosaan}

Pada kasus kekerasan seksual, dampak lain adalah kehamilan, pihak sekolah yang mengambil keputusan dengan mengeluarkan siswinya dari sekolah karena dampak kehamilan yang disebabkan dari tindakan kekerasan seksual merupakan suatu pelanggaran terhadap Hak Anak, utamanya pada hak untuk mendapatkan pendidikan yang layak. Pada pasal 31 ayat (1) dan (2) UUD 1945, merupakan suatu dasar terhadap pola atau teknik pada pendidikan nasional, hal tersebut menyatakan bahwasannya:

"(1) Setiap warga Negara berhak mendapatkan pendidikan

(2) Setiap warga Negara wajib mengikuti pendidikan dasar dan Pemerintah Wajib membiayainya".

Hak anak juga terdapat pada beberapa pasal, selain dari pasal di atas, hak anak untuk mendapatkan suatu pendidikan juga tercantum pada pasal 4 ayat (1) UndangUndang Nomor 20 tahun 2003 Tentang Sistem Pendidikan Nasinal, bahwasanya di dalam pelaksanaan pendidikan, pelaksanaan tersebut harus dilaksanakan secara demokratis, adil serta tidaknya adanya sifat diskriminatif dengan mengangkat harkat dan martabat pada HAM, norma-norma, kerohanian, dan juga sifat berbangsa dan cinta tanah air. Karena pada praktiknya banyak sekali kasus diskrimani pada anak.

Sekolah adalah tempat untuk menempuh pendidikan pada anak, dimana masa depan anak ada dalam pendidikan. Korban dari pemerkosaan seharusnya mereka terjamin dalam pendidikannya, mereka harus mendapat perlakuan yang baik dari lingkungan sekitar, sekolah juga harus memerhatikan juga siswinya yang menjadi korban kekerasan seksual ini, dalam hal ini mereka tidak memiliki kewenangan untuk mengeluarkan korban kekerasan seksual ini, karena pihak sekolah tidak boleh memandang kasus tersebut sebagai aib yang akan mencoreng nama baik sekolahnya. Terutama pada pemerintahan pusat juga harus bertindak tegas pada kasus seperti ini (KBR68H, 2013).

Jika dipandang pada perspektif hukum, sebenarnya korban dari kekerasan seksual yang sedang hamil memiliki kedaulatan yang sama di mata hukum. Karena mereka lebih pasrah dari keadaannya, dimana pihak sekolah yang mengambil putusan untuk mengeluarkannya tidak dapat dijadikan sebagai batu sandung pada penegakan HAM. Maklumat HAM sendiri dibentuk oleh PBB ditahun 1948. Pada tahun 1948, PBB membentuk dan merancang maklumat HAM yang berisikan: 
"setiap anak manusia dilahirkan dengan martabat yang sama dan punya hak yang sama dimata hukum untuk dihormati kebebasannya. Ini berlaku tanpa membedakan ras, etnis, agama, bangsa atau gender sekalipun, yang intinya nilai-nilai kemanusiaan dengan menjunjung tinggi nilai-nilai non diskriminasi" (Sadli, 2010).

Dalam hal keadilan, siswi korban pemerkosaan harus menjadi yang utama dalam perlindungannya, apalagi pada keadaan ini mereka adalah pihak yang paling dirugikan, karena dipandang dari segi fisik psikis terluka ditambah hamil karena hal yang tidak diinginkan. Mereka harus diberikan jaminan bahwasanya dalam segala bantuan terutama pada tahap rehabilitasi serta dispensasi untuk dapat melanjutkan pendidikannya supaya dapat terciptanya keadilan yang semestinya ada pada setiap warga negara dan semestinya bisa terpenuhinya pada kehidupan ini (Mulyadi, 2003).

Dengan memberikan perlindungan hukum terhadap siswi yang dikeluarkan pihak Sekolah karena hamil yang terkandung pada Undang-Undang No.35 Tahun 2014 Tentang Perlindungan anak, Untuk memenuhi serta melindungi keberpihakan kepada anak dan memangku suatu pandangan anti intoleran, kebutuhan paling mendalam bagi anak (the best interest of child), dan melibatkan kultur rohani, pastipasi masyarakat, media massa, dunia bisnis serta media internasional adalah bagian dari cara untuk memenuhi serta cara untuk menjamin hak anak yang paling efektif.

\section{Upaya penanggulangan anak korban kekerasan seksual}

Di Indonesia sendiri, upaya dalam mencegah dan penanganan kasus kekerasan seksual belum berjalan dengan baik, hal ini memyebabkan kasus kekerasan ini selalu bertambah. berbagai usaha untuk menangani kasus ini sendiri terkesan cuma-cuma karena hal inti dari permasalahan ini masih belum diperhatikan dengan baik, terlihat dari banyaknya faktor dari kasus ini sebagai contoh banyaknya penyuluhanpenyuluhan tentang sex tetapi hal untuk memicu rangsangan seks masih tetap terlihat dengan jelas seperti mudahnya dalam mengakses konten video porno, maraknya penjualan minuman keras, dan sebagainya. Sanksi yang dijatuhkan pun terbilang masih ringan, tanpa adanya sanksi yang tegas membuat tindakan ini semakin marak terjadi, bahkan hal ini membuat para pelaku tidak jera hingga menimbulkan bertambahnya pelaku-pelaku lain. Jadi usaha dalam mencegah tindakan kekerasan seksual ini masih belum sempurna terkait dalam hal tersebut.

Dalam keadaan seperti itu bisa dipandang dari sebagian situasi yang seharusnya ditangani bersama-sama (Agnitasari, 2017):

(1) status tingkat mencegah dan menangani,

(2) status pemahaman dan kesadaran masyarakat,

(3) status pengelolaan

Dalam mencegah dan menangani kasus kekerasan seksual yang harus diperhatikan pertama adalah mengenai suatu kualitas dalam menangani dan pencegahannya, kedua hal ini tidak bisa dilepaskan karena dalam mencegah dan 
menangani selalu berkaitan. Dalam mencegah akibat negatif dari kasus ini yang dirasakan pada korban adalah dengan cara rehabilitasi, rehabilitasi ini sangat efektif dalam mengatasi kondisi psikis yang terluka, cara ini bisa dilakukan di lingkungan sekitar, karena jika lingkungan sekitar mendukung maka hal ini bisa menjadikannya obat pada luka batin korban. Dalam hal ini lingkungan sekitar atau masyarakat harus meningkatkan kesadaran dan pemahamannya akan seksualitas, karena selain menjadi obat, dalam lingkungan sekitar sendiri juga terkadang dapat menjadi momok bagi korban. Yang kedua, yaitu dengan cara mengelola instansi pada sistem pemerintah dengan baik serta dengan membentuk kebijakan yang tegas dan berkomitmen. Dengan melibatkan beberapa lembaga lainnya dibawah koordinasi walikota, lembaga-lembaga seperti KPAI serta lembaga lainnya harus saling bekerja sama serta meningkatkan tanggungjawab yang kuat akan mencegah dan menanggulangi kasus kekerasan seksual ini pada setiap daerah (Agnitasari, 2017).

Selain itu setiap daerah juga harus meningkatkan kesadarannya serta kerja samanya dalam penanggulangan tindakan kekerasan ini. Yang terakhir, dengan ditingkatkannya serta diperbaikinya partisipasi masyaratakat demi menopang upaya mencegah kekerasan seksual bagi anak, pemerintah juga harus berpartisipasi dengan masyarakat karena dalam hal ini masyarakat akan patuh kepada pemimpin. Gerakan yang dapat dilaksanakan pada aspek ini adalah dengan memberikan laporan atau informasi yang efektif tata cara penanggulangan, dengan membentuk kegiatankegiatan yang kaitannya mencegah kekerasan seksual pada anak dalam setiap daerah $\mathrm{rt} / \mathrm{rw}$ atau tingkat kelurahan, serta dengan meningkatkan progam swadaya pada masyarakat, hal ini dapat membantu dalam pencegahan serta dapat menghindari pandangan negatif serta perbuatan diskrimanitf pada anak korban kekerasan seksual.

\section{Pentingnya Sex Education Pada Pelajaran Sekolah}

Selama ini, beberapa orang dalam pandangannya berbicara seks selalu merujuk pada hubungan seksual. Sedangkan maksud dari seks itu sendiri bukan hanya tentang berhubungan seksual saja, tetapi secara biologis, seks itu sendiri berkaitan dengan gender manusia. Masyarakat kita masih beranggapan tabu bila berbicara tentang seks, anggapan mereka yaitu sex education justru mendorong agar remaja berhubungan seks. Seolah berbicara tentang seks merupakan suatu hal yang sangat vulgar.

Pentingnya Pendidikan Seks bagi Remaja:

1. Agar remaja mengetahui informasi seksual

2. Supaya terciptanya kesadaran dan paham arti penting pada seksualitas

3. Adanya pemahaman tentang kegunaan alat vital

4. Menafsirkan setiap problema seksualitas pada remaja

5. Menafsirkan sebab akibat yang dapat memunculkan problema seksualitas

Faktor lain dari pentingnya sex education pada pendidikan remaja dua diantaranya adalah (Fahmawati, 2016): 
1. Karena seorang anak yang pada masa akil balik atau masa-masa keremajaan, mereka cenderung akan mencari jati dirinya, sifatnya masih labil serta tingginya sifat penasarannya, apalagi pemahamannya tentang seks masih minim sekali, hal ini akan membuat diri mereka menjadi bebas serta mereka masih tidak mampu dalam menanggung akibatnya dari seks itu sendiri. Terkadang para orang tua tidak pernah memberi pehaman tentang seks pada anaknya, karena mereka menganggap hal ini tidak pantas dibicarakan pada anak, padahal hal tersebut akan membahayakan baik dari segi kesehatan serta tindakan-tindakan yang tidak diinginkan.

2. Pendukung sex education yang kedua, dikarenakan pola pikir pada anak remaja pada seks belum matang, jadi hal semacam ini akan menyebabkan sex bebas dikalangan remaja, atau para anak usia remaja sudah melakukan having sex, akibatnya sendiri banyak sekali seusia anak SMP harus merelakan pendidikannya lantaran hamil, akibat yang paling berbahaya adalah dampak dari penyebaran penyakit menular yaitu HIV/AIDS. Hal ini juga nampak karena era sekarang semakin mudahnya untuk mengakses segala hal, para anak seusia remaja sendiri mudah sekali untuk terpengaruh hal-hal negatif dari internet, television, majalah, dan sebagainya.

Maka sangat penting adanya Kurikulum mengenai pendidikan seks bagi anak di sekolah. Dan juga berdasarkan hasil penelitian kami, banyak sekali yang setuju dengan adanya pelajaran tambahan tentang sex education di sekolah, dengan alasan karna kurangnya pengetahuan tentang sex yang menjadi faktor besar anak-anak menjadi korban pemerkosaan.

\section{KESIMPULAN}

Pemerkosaan yaitu perbuatan atau suatu kejahatanyang merajuk pada berhubungan seksual yang berlangsung pada saat setiap individu atau lebih, dengan cara memaksa wanita untuk berhubungan badan atau berhubungan seksual dengan ancaman kekerasan. Kasus kekerasan seksual sendiri sering terjadi pada kaum hawa, terlebih lagi pada anak-anak.

Berbagai faktor yang mempengaruhi kasus pemerkosaan terjadi pada anakanak yaitu, faktor yang pertama yaitu fisik pada anak yang lemah sehingga tidak dapat melakukan perlawanan, yang kedua yaitu, karena teknologi yang semakin canggih sehingga situs atau konten porno dapat dijangkau semua kalangan, sehingga mengakibatkan gairah seks sehabis menonton atau melihat konten porno dan terlintas pikiran untuk melakukan tindakan keji memperkosa lawan jenisnya, dan yang ketiga yaitu, karena kurangnya penggetahuan anak tentang seks, sehingga mereka tidak mengerti arti penting dari tubuh mereka, dan mudahnya dirayu atau dibujuk oleh pelaku kejahatan seksual. Karena anggapan masyarakat mengenai seks yang sangat tabu.

Anak korban pemerkosaan mempunyai hak untuk dijamin pendidikannya berdasarkan Undang-undang No. 39 tahun 1999 tentang Hak Asasi Manusiapasal 12 
dan 60 dan juga lembaga. Lembaga pendikan dan pemerintah harus melindungi identitas anak dari media massa agar menghindari labelisasi pada anak korban pemerkosaan. Dan juga lembaga pendidikan tidak akan mengeluarkan peserta didik yang menjadi korban pemerkosaan dari sekolah dengan alasan apapun.

Dengan adanya kejahatan seksual pada anak maka pentingnya pelajaran tambahan mengenai seks di sekolah yang berfungsi, agar anak mengetahui informasi tentang seks dan juga agar mereka tumbuh pemahaman bahwa dalam problema seksualitas sangat relevan, serta memahami juga kegunaan, makna, dan tata cara melindungi alat vital mereka. Hal semacam ini akan berguna bagi mereka dan akan menjadi bekal untuk melindungi dari kejahatan seksual.

Saran kami bagaimana diterapkannya pola pikir yang dewasa, atau bisa dengan menjauhi apapun yang berbau pornografi, saran ini terkhusus untuk para laki-laki, bisa juga dengan mengkuatkan iman setiap individu dengan beragama. Yang ketiga untuk para lembaga pendidikan, khususnya pihak sekolah tidak boleh memandang kasus-kasus kejahatan seksual ini sebagai aib, dikarenakan korban juga sebagai penerus bangsa, dan juga kususnya dinas pendidikan hingga kementrian haruslah serius dalam menangani kasus seperti ini. Saran keempat demi mencegahnya pelecehan seksual, pelajaran tentang seks harus diberikan sejak SD karena pada bangku SD anak-anak masih polos, yang ditakutkan adalah candaan mereka bisa merujuk ke pelecehan seksual atau bahkan kekerasan seksual

\section{DAFTAR PUSTAKA}

Agnitasari, Winda. (2017). Tinjauan Yuridis Viktimologis Mengenai Siswi Sma Korban Pemerkosaan Yang Dikeluarkan Dari Sekolah Karena Hamildihubungkan Dengan Uu No 35 Tahun 2014. Bandung: UNIPAS.

Butarbutar, Elisabeth Nurhaini. (2018). Langkah-Langkah Untuk Menemukan Kebenaran Dalam Ilmu Hukum/ Medan: REFIKA.

Ekandari, Mustaqfirn Faturochman. (2001). Perkosaan, Dampak, Dan Alternatif Penyembuhan, Jurnal Prikologi, 1.

Emmanuel, Sujatmoko. (2010). Hak Warga Negara Dalam Memperoleh Pendidikan. Jurnal Konstitusi, 7 <https://media.neliti.com/media/publications/110344-IDhak-warga-negara-dalam-memperoleh-pendid.pdf>.

Fahmawati, Fahriyah. (2016). Pentingnya Kurikulum Pendidikan Seks Untuk Sekolah Menengah Atas', Kompasiana, <https://www.kompasiana.com/iffahfahmawati/5687d7b4927e61b80a379a22 /pentingnya-kurikulum-pendidikan-seks-untuk-sekolah-menengah-atas> [accessed 14 June 2020].

Ilmu, Dalam. (2019). Menurut Dinas Pemberdayaan Perempuan Dan Perlindungan 
Anak Kota Semarang SKRIPSI Diajukan Untuk Memenuhi Salah Satu Syarat Guna Memperoleh Gelar Sarjana.

KBR68H. (2013). Siswi Korban Perkosaan Tetap Punya Hak Bersekolah. $<$ https://kbr.id/editorial/102013/siswi_korban_perkosaan_tetap_punya_hak_bersekolah/67913.html> [accessed 15 June 2020].

Mulyadi, Lilik. (2003). Kapita Selekta Hukum Pidana Kriminologi Dan Victimologi Denpasar: Djambatan.

Sadli, Saparinah. (2010). Berbeda Tapi Setara: Pemikiran Tentang Kajian Perempuan. Jakarta: PT Kompas Media Nusantara.

Wahid, Abdul. (2007). Perlindungan Hukum Terhadap Korban Kekerasan Seksual. Depok: Gagas Media.

Yanhtzi, Mark. (2009). Kekerasan Seksual Dan Pemulihan. Jakarta: Andi Publisher. 